\title{
Effects of Supplementation of Fructooligosaccharide and/or Bacillus Subtilis to Diets on Performance and on Intestinal Microflora in Broilers
}

\begin{abstract}
A total of 720 newly-hatched Arbor Acres broilers were selected to investigate the effects of fructooligosaccharide (FOS) and B. subtilis on performance and microbial gut concentration in broilers. The result indicated that dietary supplementation with FOS or Bacillus in comparison to an antibiotic had selective effects on increasing caecal concentration of beneficial bacteria such as Lactobacillus and decreasing concentration of harmful bacteria such as E. Coli and Salmonella. However, supplemental aureomycin had non-selective effects on caecal microflora which inhibited all bacteria. Moreover, the combination of FOS and B. subtilis had much better improvement on caecal micro-ecosystem for broiler than they were used solely. Dietary addition of FOS or B. subtilis improved performance of broilers to the levels of those fed the diet with aureomycin and the combination of FOS and bacillus had better effects on reducing diarrhea rate and promoting growth than they were used solely.
\end{abstract}

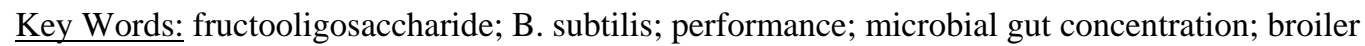

\section{Zusammenfassung}

Titel der Arbeit: Effekt einer Futterergänzung mit Fruktooligosachariden und/oder Bazillus Subtilis auf Leistungen und die Darmmikroflora bei Broilern.

An 720 frisch ausgebrüteten Arbor Acres Broilern wurde der Einfluss einer Futterergänzung mit Fruktooligosachariden (FOS) und Bacillus subtiles auf die Leistungen und die Darmflore bis zur 6. Lebenswoche untersucht. Die Ergebnisse zeigen, dass eine Futterergänzung mit FOS oder B. subtiles im Vergleich zu einer Antibiotikaanwendung einen selektiven Effekt auf die zunehmende Konzentration erwünschter Bakterien wie Laktobazillus und eine Verringerung der Konzentration unerwünschter Bakterien wie E. coli und Salmonella aufwies. Eine Aureomyzinzugabe hatte keinen selektiven Effekt bei der Beeinflussung der Darmmikroflora, da sie eine Einschränkung aller Bakterien zur Folge hatte. Außerdem ergab die Kombination von FOS mit $B$. subtilis eine Verbesserung der erwünschten bakteriellen Mikrodarmflora als dies bei einer Einzelanwendung erreicht wurde. Die Futterergänzung mit FOS oder B. subtilis verbesserte die Leistung der Broiler im Vergleich einer Zugabe mit Aureomyzin. Die Kombination beider erreichte einen besseren Effekt hinsichtlich einer Reduzierung der Durchfallrate und das Wachstum wurde besser gefördert als bei einer Anwendung von nur einem der beiden untersuchten Futterergänzungen.

Schlüsselwörter: Fruktooligosacharide, Bacillus subtilis, Wachstumsleistung, Darmmikroflora, Broiler

\section{Introduction}

It is now well known that there is a need to design feeding strategies that do not rely on in-feed antimicrobials (MUIRHEAD, 1998). One possible alternative to the use of growth promoting antibiotics might be found in prebiotics and probiotics. Prebiotics are food ingredients that selectively stimulate the activity and/or growth of beneficial bacteria such as bifidobacteria and lactobacilli (GIBSON and ROBERFROID, 1995). They are short-chain carbohydrates that are non-digestible oligosaccharides (NDO) by animal enzymes (QUIGLY et al., 1999). The selective utilization of fructooligosaccharide (FOS) by intestinal bacteria led to a remarkable increase in 
bifidobacteria in the gut according to HIDAKA et al. (1986). On the other hand, HOUDIJK (1998) concluded that FOS was fermented before it reached the colon, and therefore could not serve as substrate for bifidobacteria. HOWARD (1995) suggested that the dietary consumption of FOS tended to enhance bifidobacteria population and prevent colonic epithelial mucosa atrophy. Probiotics were defined as "live microorganisms administered in adequate amounts that confer a beneficial health effect on the host", which favorably alter the intestinal microflora balance, inhibit the growth of harmful bacteria, promote good digestion, boost immune function, and increase resistance to infection (HERICH et al.,1998; AYISIGI et al.). Prebiotics and probiotics all can adjust the intestinal microecological environment in animals, but their function mechanisms are different and probiotics were not stable in the gut. So the objective of this study is to investigate effects of FOS, B. subtilis and the combination on performance and microbial gut concentration in broilers in comparison with a feed antibiotic. There are many papers that reported feeding strategies using pro- and prebiotics in animals (BARROW, 1992; NAHASHON et al., 1994, 1996; JIN et al., 1997). However, the number of studies using a symbiotic is limited, and in this work, both a negative and a positive control have been used.

Table 1

Composition and nutritive value of experimental diet (as feed basis) (Futterzusammensetzung der Standardration)

\begin{tabular}{|c|c|c|}
\hline \multirow{2}{*}{ Subject } & \multicolumn{2}{|c|}{ Week } \\
\hline & $0 \sim 3$ & $3 \sim 6$ \\
\hline \multicolumn{3}{|l|}{ Ingredient / \% } \\
\hline Corn, ground & 53.62 & 59.78 \\
\hline Soybean, extruded & 39.00 & 33.23 \\
\hline Vegetable oil & 3.67 & 3.82 \\
\hline Limestone, ground & 0.96 & 1.04 \\
\hline Dicalcium phosphate & 1.78 & 1.28 \\
\hline Salt, iodized & 0.30 & 0.30 \\
\hline L-lysine $\mathrm{HCl}$ & 0.02 & 0.06 \\
\hline Met & 0.17 & 0.06 \\
\hline Choline & 0.20 & 0.15 \\
\hline Vitamin Premix $^{1}$ & 0.03 & 0.03 \\
\hline Microelement Premix ${ }^{(1)}$ & 0.15 & 0.15 \\
\hline Enzyme preparation complex & 0.10 & 0.10 \\
\hline Total & 100.00 & 100.00 \\
\hline \multicolumn{3}{|l|}{ Nutrient level $^{2} / \mathrm{MJ} / \mathrm{kg}$ 、\% } \\
\hline $\mathrm{DE}$ & 12.55 & 13.15 \\
\hline $\mathrm{CP}$ & 21.50 & 19.20 \\
\hline $\mathrm{Ca}$ & 1.00 & 0.90 \\
\hline Effective P & 0.45 & 0.35 \\
\hline Lys & 1.10 & 1.00 \\
\hline Met & 0.50 & 0.38 \\
\hline
\end{tabular}

Note: (1) Vitamin Premix provided the following per kg feed: Vitamin A 5500IU; D3 650IU; E 35IU; K3 2.5mg; B3 7.5mg; B6 18.6mg; B6 1.6mg; B12 100ug; Niacin 45.0mg; Vitamin H 025mg; Microelement Premix provided the following per kg feed: Cu 25mg; Fe 240mg; Mn 180mg; Zn 120mg; I 0.3mg; Se 0.5mg; (2) While the values for CP and Ca were analyzed on the spot, others were calculated.

\section{Animals and Diets}

\section{Materials and Methods}

A total of 720 newly-hatched Arbor Acres broilers of only one gender ( 5 treatments $\times 6$ replicates $\times 24$ birds $=720$ broilers ) were used. The diets consisted of a control diet, the control diet with addition of $0.3 \%$ FOS, the control diet with addition of $0.1 \% B$. 
subtilis, the control diet with addition of $0.3 \%$ FOS and $0.1 \%$ B. subtilis, and the control diet with $150 \mathrm{mg} / \mathrm{kg}$ aureomycin. Basic diet was formulated to meet or exceed the nutrient requirements (NRC, 1994) and shown on Table 1.

Each coop contained a self-feeder and a nipple to provide ad libitum access to feed and water. Animal handling procedures were in accordance with guidelines approved by China Agricultural University's Animal Care Committee. The test place was the henhouse of our university.

\section{FOS and B. subtilis}

FOS and B. subtilis were provided by the School of food science and technology, Southern Yangtze University. They were manufactured there. Based on high performance liquid chromatography (HPLC) analysis (Gan Binbin, 1999), the FOS contained $1.83 \%$ monosaccharides, $1.13 \%$ sucrose, $39.81 \%$ kestose, $49.78 \%$ nystose, $7.06 \%$ furanosyl nystose, for a total FOS of $96.65 \%$. The concentration of B. subtilis was $60 \times 10^{9} / \mathrm{g}$.

\section{Performance}

Body weight was measured at the 1st, the 3rd and the 6th week and feed consumption was measured at the end of the 3rd and 6th week. The average daily gain, average food intake and feed conversion rate (feed intake divided over weight gain) were measured respectively. The health of broilers was recorded daily, diarrhea rate and death rate were then calculated at the same time. The parameter of diarrhea was that there was obvious dejecta around the exit of cloacae.

\section{Microbial gut concentration}

Six broilers were selected randomly from each group at the 3rd week and the 6th week, anesthetized by injecting natrium pentobarbital. $2 \mathrm{~cm}$ of caecum was immediately collected upon the animals and frozen in a liquid nitrogen kettle until subsequent analysis.

Samples were diluted to $10^{-4} \sim 10^{-9}$ times on ultraclean operation desk. The concentration of E. coli, Salmonella, Lactobacillus and total aerobe counts were assessed. With the differences of nutritional needs and growth conditions, E. coli, Salmenella and Lactobacillus were determinated by selective mediums, accompanied by the corresponding environmental conditions. For the demands of the nutritional needs of all aerobes, total aerobe counts were detected by Nutrient Agar. The specific steps are as follows: Concentration of E. coli, Salmonella and total aerobe counts were measure as follows: 200ul diluent of caecum content was respectively planted on EMB Agar, SS Agar and Nutrient Agar (3 concentrations $\times 3$ replicates). Petri dishes were cultured $24 \mathrm{~h}$ in $37^{\circ} \mathrm{C}$ oxygenic incubator, then the number of colonies were recorded. Concentration of Lactobacillus was measure as follows: 200ul diluent of caecum content was planted on LBS Agar (3 concentrations $\times 3$ replicates). Petri dishes were put into anaerobic kettle and cultured $48 \mathrm{~h}$ in $37^{\circ} \mathrm{C}$ incubator, then the number of colonies were recorded. 
The number of colonies of the optimal culture plate which had about 30 300 colonies were recorded, then the average and the concentration of bacteria per $1 \mathrm{~g}$ caecum content (LogCFU/ g) were calculated.

\section{Statistical analysis}

Data were analyzed using one-way ANOVA procedures by SPSS11.0. Duncan's multi-comparison was used to test significance and probability values of $P<0.05$ were taken as significant.

\section{Results \\ Performance}

Table 2 showed that the average daily gain was significantly increased by using FOS, $B$. subtilis and FOS $+B$. subtilis during the whole broilers' growing period ( $0 \sim 6$ week) $(\mathrm{P}<0.05)$, but the effect of FOS was not obvious during $0 \sim 3$ week. Antibiotics significantly increased average daily gain during $0 \sim 3$ week $(\mathrm{P}<0.05)$, but this effect didn't come out during 0 6 week. FOS, B. subtilis, FOS + B. subtilis and antibiotics all could significantly improve feed conversion rate during the whole broilers' growing period $(0 \sim 6$ week) $(\mathrm{P}<0.05)$, but the effect of antibiotics mainly occured during $0 \sim 3$ week which was different from others. There were no significant differences in average food intake among the treatment groups $(\mathrm{P}>0.05)$. Diarrhea incidences mainly occurred during $0 \sim 3$ week, The antibiotics group had the lowest the diarrhea rate, and the next was the $B$. subtilis group and the FOS $+B$. subtilis group, there were no significant differences between the FOS group and the control group $(\mathrm{P}>0.05)$. In this experiment, the death rate was low and difference of death rate wasn't obvious among the treatment groups $(\mathrm{P}>0.05)$.

Table 2

Effects of FOS and B. subtilis on Performance in Broilers (Einfluss von FOS und B. subtilis auf die Leistungen der Broiler)

\begin{tabular}{|c|c|c|c|c|c|}
\hline Treatments & Control & $\begin{array}{c}\text { Fructooligo- } \\
\text { saccharide }\end{array}$ & B. subtilis & FOS + B. subtilis & Antibiotic \\
\hline \multicolumn{6}{|c|}{ Average daily gain /g } \\
\hline $0 \sim 3$ week & $32.1 \pm 3.1^{\mathrm{a}}$ & $33.1 \pm 3.8^{\mathrm{ab}}$ & $33.6 \pm 2.6^{b}$ & $33.7 \pm 2.2^{b}$ & $33.9 \pm 1.9^{b}$ \\
\hline 3 6 week & $66.4 \pm 5.0^{\text {a }}$ & $70.0 \pm 5.2^{b}$ & $69.5 \pm 6.3^{b}$ & $70.4 \pm 4.6^{b}$ & $68.2 \pm 3.3^{\text {a }}$ \\
\hline $0 \sim 6$ week & $49.2 \pm 4.3^{\mathrm{a}}$ & $51.6 \pm 4.8^{b}$ & $51.6 \pm 5.7^{\mathrm{b}}$ & $52.1 \pm 4.0^{\mathrm{b}}$ & $51.1 \pm 3.0^{\mathrm{ab}}$ \\
\hline \multicolumn{6}{|c|}{ Average daily intake /g } \\
\hline $0 \sim 3$ week & $46.9 \pm 5.5$ & $47.9 \pm 6.9$ & $47.9 \pm 5.7$ & $48.2 \pm 6.7$ & $47.5 \pm 5.4$ \\
\hline 3 6 week & $141.9 \pm 12.6$ & $147.1 \pm 13.6$ & $145.5 \pm 13.9$ & $147.8 \pm 14.2$ & $145.7 \pm 12.5$ \\
\hline 0 6 week & $94.4 \pm 9.6$ & $97.5 \pm 10.1$ & $96.7 \pm 9.9$ & $98.0 \pm 11.4$ & $96.6 \pm 9.6$ \\
\hline \multicolumn{6}{|c|}{ Feed conversion rate } \\
\hline 0 3 week & $1.46 \pm 0.17$ & $1.45 \pm 0.21$ & $1.42 \pm 0.13$ & $1.43 \pm 0.12$ & $1.40 \pm 0.10$ \\
\hline 3 6 week & $2.14 \pm 0.15^{b}$ & $2.10 \pm 0.11^{\mathrm{a}}$ & $2.09 \pm 0.08^{\mathrm{a}}$ & $2.10 \pm 0.10^{\mathrm{a}}$ & $2.14 \pm 0.08^{b}$ \\
\hline $0 \sim 6$ week & $1.92 \pm 0.16^{\mathrm{b}}$ & $1.89 \pm 0.12^{\mathrm{a}}$ & $1.88 \pm 0.10^{\mathrm{a}}$ & $1.88 \pm 0.11^{\mathrm{a}}$ & $1.89 \pm 0.08^{a}$ \\
\hline \multicolumn{6}{|c|}{ Diarrhea rate $/ \%$} \\
\hline 0 3 week & $33.69 \pm 6.39^{c}$ & $26.34 \pm 7.72^{\mathrm{cb}}$ & $15.62 \pm 3.81^{\mathrm{b}}$ & $14.31 \pm 4.67^{\mathrm{b}}$ & $7.45 \pm 3.28^{a}$ \\
\hline 3 6 week & $3.27 \pm 0.29^{b}$ & $1.43 \pm 0.12^{\mathrm{a}}$ & $1.76 \pm 0.11^{\mathrm{a}}$ & $1.52 \pm 0.09^{\mathrm{a}}$ & $4.13 \pm 0.15^{b}$ \\
\hline 0 6 week & $18.48 \pm 2.83^{\mathrm{C}}$ & $13.89 \pm 1.96^{\mathrm{cb}}$ & $8.69 \pm 1.06^{b}$ & $7.77 \pm 1.18^{b}$ & $5.79 \pm 0.67^{\mathrm{a}}$ \\
\hline \multicolumn{6}{|l|}{ Death rate $/ \%$} \\
\hline 0 3 week & $2.78 \pm 4.30$ & $1.39 \pm 3.40$ & $1.39 \pm 3.40$ & $1.39 \pm 3.40$ & $1.39 \pm 3.40$ \\
\hline 3 6 week & $1.43 \pm 3.40$ & 0 & 0 & 0 & $1.41 \pm 3.40$ \\
\hline 0 6 week & $4.17 \pm 6.45$ & $1.39 \pm 3.40$ & $1.39 \pm 3.40$ & $1.39 \pm 3.40$ & $2.78 \pm 3.40$ \\
\hline
\end{tabular}

Note: Values are mean \pm std. Error; Different superscripts within a row indicates significant differences (P<0.05); No superscripts or same superscripts within a row indicates no significant difference $(\mathrm{P}>0.05)$. Similar to the next table. 


\section{Intestinal microflora}

Table 3 showed that groups of FOS and FOS $+B$. subtilis all could decrease the concentration of E. coli, total aerobe counts, Salmonella and increased concentration of Lactobacillus on caecal microflora, which was more obvious along with the broilers' growth $(\mathrm{P}<0.05)$, and the effect of FOS $+B$. subtilis was the more stronger than the other one during $0 \sim 6$ week. Although $B$. subtilis also decreased the concentration of $E$. coli, total aerobe counts, Salmonella and increased concentration of Lactobacillus in 0 3 week, the effect was weak after the 3rd week. There was no significant decrease on the concentration of $E$. coli and total aerobe counts of the FOS group at the 3rd week, but this decrease was obvious after the 3rd week. We could conclude that there was a synergistic action between FOS and B. subtilis. Aureomycin had a significant effect on inhibiting the concentration of $E$. coli, total aerobe counts, Salmonella and Lactobacillus that was different from FOS and B. subtilis $(\mathrm{P}<0.05)$, and this effect was weaker along with broilers' growth.

Table 3

Effects of FOS and B. subtilis on intestinal microflora population in broilers (LogCFU/g) (Einfluss von FOS und B. subtilis auf die Mikroflorapopulation des Darmes bei Broilern)

\begin{tabular}{|c|c|c|c|c|c|}
\hline Treatment & Control & $\begin{array}{l}\text { Fructooligo- } \\
\text { saccharide }\end{array}$ & B. subtilis & FOS + B. subtilis & Antibiotic \\
\hline \multicolumn{6}{|l|}{3 week } \\
\hline $\begin{array}{l}\text { Total aerobe } \\
\text { counts }\end{array}$ & $8.91 \pm 0.27^{a}$ & $8.79 \pm 0.38^{\mathrm{ab}}$ & $8.67 \pm 0.34^{\mathrm{ab}}$ & $8.49 \pm 0.21^{b}$ & $7.95 \pm 0.18^{\mathrm{c}}$ \\
\hline E. coli & $8.64 \pm 0.39^{a}$ & $8.53 \pm 0.17^{\mathrm{a}}$ & $8.16 \pm 0.36^{b}$ & $8.21 \pm 0.27^{b}$ & $7.52 \pm 0.26^{c}$ \\
\hline Salmonella & $6.95 \pm 0.47^{\mathrm{a}}$ & $6.03 \pm 0.35^{b}$ & $6.19 \pm 0.26^{b}$ & $5.46 \pm 0.32^{c}$ & ND \\
\hline Lactobacillus & $7.30 \pm 0.34^{\mathrm{c}}$ & $8.18 \pm 0.38^{b}$ & $8.03 \pm 0.29^{b}$ & $8.45 \pm 0.19^{a}$ & $6.75 \pm 0.48^{d}$ \\
\hline \multicolumn{6}{|l|}{6 week } \\
\hline $\begin{array}{l}\text { Total aerobe } \\
\text { counts }\end{array}$ & $8.79 \pm 0.25^{a}$ & $8.21 \pm 0.18^{b}$ & $8.35 \pm 0.28^{b}$ & $7.86 \pm 0.33^{c}$ & $8.29 \pm 0.27^{b}$ \\
\hline Coli bacillus & $8.43 \pm 0.28^{a}$ & $7.65 \pm 0.19^{b}$ & $7.78 \pm 0.35^{b}$ & $7.59 \pm 0.37^{b}$ & $7.62 \pm 0.31^{b}$ \\
\hline Salmonella & $6.89 \pm 0.31^{a}$ & $5.92 \pm 0.23^{b}$ & $6.14 \pm 0.27^{b}$ & $5.58 \pm 0.19^{c}$ & $5.87 \pm 0.21^{b}$ \\
\hline Lactobacillus & $8.12 \pm 0.28^{c}$ & $8.89 \pm 0.25^{b}$ & $8.76 \pm 0.33^{b}$ & $9.37 \pm 0.26^{\mathrm{a}}$ & $7.93 \pm 0.38^{\mathrm{c}}$ \\
\hline
\end{tabular}

\section{Discussion}

The use of in-feed antibiotics has until now been the main used as a modulator of colonic bacterial populations to improve host health in poultry. But approvals for the inclusion of non-therapeutic antibiotics in poultry feed are fast disappearing worldwide due to fear of development of antibioticresistant microbes. Public concern about the threat of antibiotic-resistant pathogens has forced the poultry industry to consider various other alternatives.

Numerous reports indicated that microbial additive like oligosaccharide, probiotics and their combination could regulate the intestinal microecological environment, enhance performance and health (MCGINNIS, 1992; PAN KANGCHENG and YANG, 1997; CHEN et al., 2003). It is reported that bacillus could increase the concentration of the beneficial bacteria such as Lactobacillus and Streptococcus, they could produce much organic acid which could lower the $\mathrm{pH}$ and inhibit the reproduction of the harmful bacteria's in gut. Bacillus was heat-resisting and was advantageous in the feed processing, but its application was limit because it was not stable in the gut.

The use of fructooligosaccharides (FOS) in animal nutrition has attracted considerable recent interest, primarily because they might act as a modulator of colonic bacterial 
populations and fermentation end-products potentially to improve host health (CZARNECKI-MAULDEN, 2000; FLICKINGER and FAHEY, 2002). FOS are not digested in the small intestine by endogenous enzymes, and enter the large intestine to be fermented by the microflora to produce volatile fatty acids (VFA), lactate and gases (CUMMINGS and ENGLYST, 1995; GIBSON et al., 1995; SALMINEN et al., 1998; VAN LOO et al., 1999). These properties qualify FOS as a type of dietary fibre (CUMMINGS and ENGLYST, 1995). FOS have been identified as prebiotics (GIBSON and ROBERFROID, 1995), which are food ingredients that are not digested by small intestinal enzymes but are fermented in the large intestine to stimulate selectively the growth of probiotic-like bacteria that are part of the commensal gut microflora (SALMINEN et al., 1998; MACFARLANE and CUMMINGS, 1999). GIBSON and ROBERFROID (1995) added to this definition by stipulating that the stimulation of these bacteria would improve health of the host. The gut health benefits of prebiotics include the exertion of an antibacterial effect on potentially pathogenic bacteria through production of acids which causes a reduction in intestinal $\mathrm{pH}$, reduction of ammonia levels through protonation of $\mathrm{NH}^{4+}$, production of $\mathrm{B}$ group vitamins, and immunomodulation in the gut mucosa (GIBSON and ROBERFROID, 1995). In this study, inhibitory action of oligosaccharide on E. coli and total aerobe counts was no obvious before the 3rd week but became notable at the late stage of the growth, because it needed time for FOS to adjust host's intestinal microflora. This result was in consonance with reports by Houdijk (HOUDIJK et al., 1998).

The combination of NDO and probiotics which could break up NDO could balance intestinal microecosystem, because a competitive reaction between beneficial bacteria and intrinsic intestinal microflora which improved beneficial bacteria's livability while it got across the forepart of gut and stimulated the effect of NODs on growth and activity of microflora. Therefore, the combination of oligosaccharide and probiotics could be regarded as a potential new feed additive.

\section{References}

AYISIGI, K.; ATASOGLU C.,YURTMAN I.Y., MENDES M.,PALA A.:

Effect of probiotic supplementation shortly before and after weaning on growth of Turkish Saanen kids. Arch. Tierz., Dummerstorf 48 (2005), 601-611

BARROW, P. A.:

Probiotics for chickens. in The Scientific Basis. R. Fuller, ed. Chapman and Hall, London, UK, Pages 225-257 (1992)

CHEN, XUDONG; MA, QIUGANG; JI, CHENG:

Effects of Fructooligosaccharide and Bacillus Subtilis on and Intestinal Microflora in weaned piglets. Feed In China, 18 (2003), 11-13

CUMMINGS, J.H.; ENGLYST, H.N.:

Gastrointestinal effects of food carbohydrate. Am. J. Clin. Nutr. 61 (1995), 938-945

CZARNECKI-MAULDEN, G.:

The use of prebiotics in prepared pet food. Vet. Int. 12 (2002), 19-23. Flickinger, E.A., Fahey Jr., G.C., 2002. Pet food and feed applications of inulin. Br. J. Nutr. 87 (Suppl. 2), 297-300

GAN, BINBIN:

Determines component of Fructo-oligosaccharide by the highly effective liquid chromatography. Chromatograph, 17 (1997), 87-89

GIBSON, G.R.; BEATTY, E.R.;WANG, X.; CUMMINGS, J.H.:

Selective stimulation of bifidobacteria in the human colon by oligofructose and inulin. Gastroenterology 108 (1995), 975-982

GIBSON, GR.; ROBERFROID, MB.:

Dietary modulation of the human colonic microbiota: Introducing the concept of prebiotics. J. Nutr. 125 (1995), 1401-1412 
HERICH, R.; BOIMBA, A.; NEMCOVA, R.; GANCARCIKOVA, S.:

The influence of application of probiotic on the immune system of 2-3 month old calves. Arch. Tierz., Dummerstorf 41 (1998), 565-572

HIDAKA, H.; EIDA, T. ; TAKIZAWA, T.; TOKUNAGA, T.; TASHIRO, Y.:

Effects of fructooligosaccharides on intestinal flora and human health. Bifidobact. Microflora. 5 (1986), 37-50

HOUDIJK, G.M.; BOSCH, M.W.; VERSTEGEN, H.J.:

Effects of dietary oligosaccharides on the growth performance and faecal characteristic of young growing pigs. Anim. Feed Sci. Technol., 71 (1998), 35-48

HOWARD, M. D.; CORDON, D. T.; PACE, L. W.; GARLEB, K. A.; KERLEY, M.S.:

Effects of dietary supplementation with fructooligosaccharides on colonic microbiota populations and epithelial cell proliferation in neonatal pigs. J. Ped. Gastroenter. Nutr. 21 (1995), 297-303

JIN, L. Z.; HO, Y. W.; ABDULLAH, N.; JALALUDIN, S.:

Probiotics in poultry: Mode of action. Worlds Poult. Sci. J. 53 (1997), 351-368

MACFARLANE, G.T.; CUMMINGS, J.H.:

Probiotics and prebiotics: can regulating the activities of intestinal bacteria benefit health? Br. Med. J. 318 (1999), 999-1003

MCGINNIS, K.:

Lactosacc versus Bacitracin in broiler starter diets. A. Proceedings of Alltech's 8th Annual Symposium. C. Alltech Technical Publications. Kentucky, USA.1992.

MUIRHEAD, S.:

EU ban of antibiotics draws sharp criticism. Feedstuffs 70 (1998) 52, 1

NAHASHON, S. N.; NAKAUE, H.S.; MIROSH, L.W.:

Production variables and nutrient retention in single comb white leghorn laying pullets fed diets supplemented with direct fed microbials. Poult. Sci. 73 (1994), 1699-1711

NAHASHON, S. N.; NAKAUE, H.S.; MIROSH, L.W.:

Performance of single comb white leghorn fed a diet supplemented with a live microbial during the growth and egg laying phases. Anim. Feed Sci. Techol. 57 (1996), 25-38

NRC.

Nutrient Requirements of Poultry. 9th rev. ed. National Academy Press, Washington, DC. 1994

PAN, KANGCHENG; YANG, HANBO:

Bacillus's mechanism of action in feed. . Feed Industry, 18 (1997) 9, 32-34

QUIGLY, ME.; HUDSON, GJ.; ENGLYST, HN.:

Determination of resistant short-chain carbohydrates (non-digestible oligosaccharides) using gas-liquid chromatography. Food Chem. 65 (1999), 381-390

SALMINEN, S.; BOULEY, C.; BOUTREN-RUAULT, M.C.; CUMMINGS, J.H.; FRANCK, A.; GIBSON, G.R.; ISOLAURI, E.; MOREAU, M.C.; ROBERFROID, M.; ROWLAND, I.:

Functional food science and gastrointestinal physiology and function. Br. J. Nutr. 80 (1998), 147-171

VAN LOO, J.; CUMMINGS, J.; DELZEENE, N.; ENGLYST, H.:

Functional food properties of non-digestible oligosaccharides: a consensus report for the ENDO project (DGXII AIRII-CT94-1095). Br. J. Nutr. 81 (1999), 121-132

Received: 2006-10-05

Accepted: 2007-09-14

Corresponding author

CHUANLAI XU, School of Food Science and Technology, Southern Yangtze University, 214122, WuXi, JiangSu Province, China

E-mail: xcl@sytu.edu.cn 